\title{
Risks of Multi-Contract in Sharia Financial Institutions, Indonesia
}

\author{
Fikri Lahafi \\ IAIN Parepare, Indonesia \\ fikristainpare@gmail.com
}

\author{
Rahman Ambo Masse \\ IAIN Parepare, Indonesia \\ rahman.ambo@yahoo.co.id
}

\author{
Syahriyah Semaun \\ IAIN Parepare, Indonesia \\ syahriyah.semaun@gmail.com
}

\author{
Wahidin \\ IAIN Parepare, Indonesia \\ wahidin@stainparepare.ac.id
}

\author{
Rusdaya Basri \\ IAIN Parepare, Indonesia \\ rusdayabasri@gmail.com
}

\begin{abstract}
The objective of this study was to explore multi-contracts on Sharia Financial Institutions which mainly consist of two problems: 1) products of Sharia Financial Institutions which are related to multi-contracts; and 2) risk accountability of multicontracts on Sharia Financial Institutions. The approach used wasa descriptive-qualitative approach and the subjects were the costumersof Sharia Financial Institutions. The data were obtained through direct observations and semi-interviews in Sharia Financial Institutions with the employees' activities. The results showed thattheproducts of Sharia Financial Institutions related to multicontractsin the DSN-MUI fatwa include musyarakah mutanaqishah, financing takeover, and sharia credit card. Every transaction in multi-contracts has a risk. Moreover, the risk is to be held accountable by all the partiesinvolved in the contract, and also risk accountabilityoccurs due to the customers' negligence of their obligations.
\end{abstract}

Keywords: Accountability, Risk, Multi-Contracts, Costumers, Sharia Financial Institutions

\section{INTRODUCTION}

Islamic law requires a freedom of transactions in the contract in whichthis must be obeyed by allparties. The law applicable in the transaction is the agreement between the parties when making the contract [1]. In determining the applicable law of the contract, one should first consider the agreement between the parties at the time of making the contract [2]. Islamic law requires the implementation of contracts from all parties without any pressure or force in the transaction.

Shariafinancial institutions have various kinds of contracts [3], such as musharakah, mudhrabah, Murabaha, ijara, salam and istisna' as contract innovations formulated into excellent products. The implementation of contracts in sharia financial institutions is implemented in accordance with the fatwa of scholars sourced from the Qur'an and Hadith. When the law is explicitly mentioned from both sources, there is no room for human'sjudgment in Islamic law[4].
Sharia financial institutions in Islamic law strongly reject riba in each transaction. As explained by the Qur'an, ribais considered inhumane; besides, there is discrimination between the borrower and the lender as well as the dominance of the rich over the poor. Many sharia financial institutions pretend to reject riba, gharar, and maysir although in its practice, they are still not able to totally apply the social values in Islamic law[5]-[8]. It means that sharia financial institutions are prohibited from making contracts in any transaction containing riba.

Shariafinancial institutions have special characteristics in providing investment and financing products where it should not deviate from sharia[9]. As such, riba has a very strong influence in the contract, so the concept should always be revised in the transactions continuously [10].Sharia financial institutions must change the paradigm of Muslims society in Indonesia to make transactions on various products.

The innovative efforts of banking products in responding to the needs of the modern society are to develop multi-contract products in modern financial transactions [11]. Multi-contractsare used in many industries to balance incentives for cost efficiency and quality [12].

One of the strategies is an innovation of the products, such as multi-contracts for the development of sharia financial institutions; in other words, sharia financial institutions must create many more innovative products in order to increase the interest of customers to overcome the very slow growth and decline in the market share.

\section{METHOD}

The aims of this study were to describe and analyze the accountability of risk in multi-contract on sharia financial institutions. This was done by using descriptivequalitative with normative theology, formal juridical and sociological approach. The design of this study was considered appropriate to produce research products validly, practically and effectively.

The sources of the data were from interviews, books, scientific articles, scientific journals, books and reports needed to sharpen the accountability of risk in multi- 
contract on sharia financial institutions. The Processing techniques and data analysis used were editing and validation. Furthermore, the data were structured on the basis of the content and structure of the discussion to obtain the validity about the concept of accountability of risk in multi-contract on sharia financial institutions.

\section{RESULT}

\section{Products of Multi-Contracts in Sharia Financial Institutions}

Multi-contract in Arabic is called al-uqud almurakkabah which means a double contract. According to Nazih Hammadthat, Al-Uqud Al-Murakkabah is a two-party agreement to carry out transactions of two or more contracts [13]. In Multi-contracts, the first contract can respond to the second contract; in addition, the interrelation and support between the fulfillment of the first contract depends on the fulfillment of the second contract, through a reciprocal process[14]-[15].

Innovations of various products that became the focus of a multi-contract are musharakah mutanaqishah, financing takeover, and sharia credit card. The multicontract innovation in musharakah mutanaqisah financing in sharia financial institutions are operated for the consumptive products in forms of home ownership by using a combined system of contracts consisting of musharakah contract, leasing, buying and selling.[16].Homeownership financing based on musharakah mutanaqisah contract is allowed and consists of musharakah or syirkah contract and sold in accordance with the fatwa of DSN No.73/DSN$\mathrm{MUI} / \mathrm{XI} / 2008$.

The multi-contract on take-over products in sharia financial institutions is currently using marketing strategy with a take-over system of residential financing. Takeover residential financing occurs with the transfer of financing facilities from one bank to another. Take-over debt is the willingness of customers to transfer their credit to other banks to make a profit. Financing products are offered by a sharia bank to its customers by using ba'imurabaha contract. Ba'imurabaha contract in Islamic law is a multi-contract, which is a combination of $b^{\prime} i$ contract and murabaha contract[17].

The first step of financing takeoverstarts with the request of customers to move its sharia financing from conventional banks to sharia bank. Then sharia bank repays the remaining debt from customers who get home loans from a conventional bank.

Besides, multi-contracts related to products in a sharia bank are considered necessary to provide convenience and security for customers in conducting the transaction and cash withdrawal by providing a credit card in accordance with the principles of sharia. DSN Fatwa No.54/DSN-MUI/X/2006 explains that a sharia card is allowed. The contracts used for sharia cards are kafalah[18],qardand ijarah. Terms of fee in sharia card include membership fee, merchant fee, cash withdrawal fee, and kafalah fee.

\section{Risk Accountability in Multi-contracts on Sharia Financial Institutions}

The risk certainty in transactions aims to prevent from the exploitation of one party to another that each transaction must be free fromany manipulation, and speculation. Islamic law prohibits any transaction which is against the inherent uncertainty of the risk amount or uncertainty that is inevitable in every transaction [19].

The determination of risk means ensuring the stability of bank management so that it may become more responsible [20]. According to R. Raymond Sant, a risk is inherent in most human endeavors, and financial risk is embedded in all loans and trading transactions run by any financial institution[21]. For sharia financial institutions in Indonesia, the risk is about a potential loss due to certain events[22].

A law principle says that "earnings are accompanied by risks"; therisk sharing of in a trading environment is also known as risk-taking. In terms of the risk distribution in transactions, the borrowers and lenders must share the risk. Therefore, it is unfair to burden all risks to customers of the bank solely[23]. It is unfortunate that the application of risk in sharia banks has the same risk as that in conventional banks. For example, the application of the credit risk in sharia banks still adopts the interest rate in conventional banks[24].

The Islamic Financial Services Board recognizes six major types of risks, namely credit risk, equity investment risk, market risk, liquidity risk, the rate of return risk, and operational risk[25].Thus, any contract on uncertain events must be avoided. The Sharia financial system strives to contribute to achieve the major socioeconomic goals of society. This system focuses on the ethical, social, and moral dimensions of wealth creation that enhances equality and fairness for society[26].

It was also found that the risk accountability in multi-contract tends to affect the sustainability of contract on musharaka mutanaqsihah. The system of execution of musharaka mutanaqsihah contract in mudharabah financing allows the bank to supervise and control the business of its customers by requesting reports on the results of management and income from mudharabah financing. The results of the mudharabah fund management report aim to determine the realization of the projected income profit after the signing of the musharaka mutanaqsihah contract.

In practice, musharaka mutanaqsihah contract is implemented consistently by Muamalat Bank Makassar branch and Sharia Business Unit of BPD South Sulawesi by always requesting a report and supporting evidence related to the mudharabah fund management. The consistency of the bank requests mudharabah fund management report is one of the preventive measures to prevent the occurrence of gharar and mudharat caused by mismanagement of mudharabah funds.

The risks of multi-contracts in Law No. 212008 consistof administrative and criminal penalties. Administrative penalties are stipulated by Bank Indonesia to a sharia bank or sharia financial institution, 
and a conventional commercial bank which has a sharia business unit that obstructs the implementation of sharia principles in carrying out its business and duties. Giving criminal penalties for not complying with sharia principles in running multi-contracts in sharia banksis a preventive effort of the government in maintaining its consistency in applying sharia principles in the funds distribution.

Multi-contracts applied to sharia banks cannot be separated from the potential risk that occurs in financing. Multi-contracts, if not supported by Islamic law, may become a way to anticipate the type of transactions containing riba to be lawful. In musharaka mutanaqsihah contract, there is an ijarah or lease contract. The increase in lease expenses on financing objects whose management and designations are not in accordance with the agreementmay potentially fall intoriba.

\section{CONCLUSION}

Musharakah mutanaqisah contract in sharia financial institution is operated in the form of consumer financing such as home ownership with capital participation scheme, ijara, as well as buying and selling.Multi-contracts in takingover products in sharia banks are currently using a marketing strategy with a take-over system of residential financing. Multi-contracts are related to products in sharia banks for customers in conducting the transaction and cash withdrawal by providing a credit card. The contracts used for sharia cards are kafalah contract, qard, and ijarah.

The risk accountability of multi-contracts in Law no. 212008 consists of administrative and criminal penalties. Administrative penalties are stipulated by anBank Indonesia to a sharia bank or sharia financial institution, and a conventional commercial bank having a sharia business unit that obstructs the implementation of sharia principles in carrying out its business and duties. Criminal penalties are also implemented for violations, such as not complying with sharia principles in running multi-contracts in sharia banks.

\section{REFERENCES}

[1] A. Abdullah, "The Doctrine of The Freedom of Contract ( Hurriyyat al-Ta' aqud ) in Islamic $\mathrm{Mu}^{\prime}$ amalat: An Exposition on The Concept And Rules of The Contract of Muqawalah in The Construction Industry," Islam. Stud., vol. 50, no. 3/4, p. 366, 2011.

[2] K. M. Al-Jumah, "Arab State Contract Disputes: Lesson From The Past," Arab Law Q., vol. 17, no. 3, pp. 215-240, 2002.

[3] G. G. Khan, "Application of Talfiq in Modern Islamic Commercial Contracts," Policy Perspect., vol. 10, no. 2, p. 134, 2013.

[4] M. Afzal, "Theory And Practice Of Islamic Banking," Pak. Econ. Soc. Rev., vol. 31, no. 2, p. 104, 1993.
[5] S. Q. Qadri, "Islamic Banking: An Introduction," Bus. Law Today, vol. 17, no. 6, pp. 58-61, 2008.

[6] D. A.Roy, "Islamic Banking," Middle East. Stud., vol. 27, no. 3, p. 427, 1991.

[7] Ahmad Hidayat, "Islamic Contracts in a Secular Court Setting? Lessons from Malaysia," Arab Law $Q$. , vol. 21, no. 4, p. 318, 2007.

[8] A. E. H. Siti Aisjah, "Performance-Based Islamic Performance Index ( Study on the Bank Muamalat Indonesia and Bank Shariah Mandiri," Asia-Pacific Manag. Bus. Appl., vol. 2, no. 2, p. 100, 2014.

[9] I. F. Wijaya, "The Objective of Islamic Bank: A Case Study In Surakarta Region," J. Keuang. dan Perbank., vol. 18, no. 3, pp. 489-496, 2014.

[10] M. Noor, "Principles of Islamic Contract Law," J. Law Relig., vol. 6, no. 1, p. 120, 1988.

[11] S. Muafi, Suwitho, Purwohandoko, Imanirrahma, "Human Capital In Islamic Bank And Its Effect On The Improvement Of Healthy Organization And Employee," Int. J. Res., vol. 11, no. 4, p. 850, 2017.

[12] A. K. and K. J. Mayer, "Relationships and Hybrid Contracts: An Analysis of Contract Choice in Information Technology," J. Law Hybrid Contract Choice Inf. Technol., vol. 20, no. 1, p. 210, 2004.

[13] N. Hammad, "Al-Uqud al-Murakkabah fi al-Fiqh al-Islam, Dirasah Ta'siliyah Lilmanzumat alAqdiyah al-Mustahdasah.” pp. 7-9, 1977.

[14] B. Lateh, "Multiple Contracts According to the Fatwa of National Sharia Council," Int. J. Nusant. Islam, vol. 4, no. 1, p. 43, 2016.

[15] M. I. S. Mihajat, "Hybrid Contract in Islamic Banking and Finance: A Proposed Shariah Principles and Parameters for Product Development," Islam. Manag. Bus., vol. 7, no. 16, p. 91, 2015.

[16] A. Firdaun, "Account Manager of Bank Muamalat, Makassar," 2014.

[17] S. H. Distie Saraswati, "Implementasi Hybrid Contract pada Take Over Pembiayaan Hunian Syariah dari Bank Konvensional ke Bank Syariah dalam Perspektif," Jurisprudence, vol. 7, no. 1, p. 81, 2017.

[18] M. Firmansyah, "Implementation of Contract Hybrid Concept in Multi Services Products ( Application of the Warranty Bank Products / Kafalah in Syariah Banks )," Int. J. Nusant. Islam, vol. 4, no. 2, pp. 85-96, 2016.

[19] N. C. Dau-Schmidt, "Forward Contracts Prohibitions on Risk and Speculation Under Islamic Law," Indiana J. Glob. Leg. Stud., vol. 19, no. 2, p. 540, 2012.

[20] B. J. Cipovova Eva, "Assessment of Credit Risk Approaches in Relation with Competitiveness Increase of the Banking Sector," J. Compet., vol. 4, no. 2, p. 72, 2012.

[21] R. R. Sant and R. W. Schroeder, "Credit Unions and Capital Adequacy: Managing Growth and Risk," Int. J. Bus. Soc. Res., vol. 6, no. 2, p. 243, 2012. 
[22] S. U. Etikah Karyani, "Ownership Concentration and Bank Risk ( A Study on Banking Sectors in Indonesia )," J. Econ. Business, Account. Ventur., vol. 18, no. 1, p. 191, 2015.

[23] N. D. T. Ousmane Diallo, Tettet Fitrijanti, "Analysis of The Influence of Liquidity, Credit and Operational Risk, in Indonesian Islamic Bank' s Financing for The Period 2007-2013," Gajah Mada Int. J. Bus., vol. 17, no. 3, pp. 279-294, 2015.

[24] F. Fakhrunnas and Z. Ramly, "Board of Directors and Risk-taking Behavior of Islamic
Banks in South East Asia," Tazkia Islam. Finance. Bus. Rev., vol. 10, no. 2, pp. 162-177, 2015.

[25] Y. A. Rashidah Abdul Rahman, Fauziah Hanim Tafri, "Instrumentsand Risks in Islamic Financial Institutions," Malaysian Account. Rev., vol. 9, no. 2, p. $17,2010$.

[26] H. Diocolano, I. Corresponding, and N. Omar, "Critical Financial Analysis of Islamic Bank in the Philippines : Case Study of Amanah Islamic Bank," GJTA, p. 149, 2018. 